\title{
Identifikasi Kesalahan Siswa dalam Menyelesaikan Materi Sistem Persamaan Linear Tiga Variabel
}

\author{
Astuti Supartinah ${ }^{1, *}$, Wahyu Hidayat ${ }^{2}$ \\ ${ }^{1,2}$ IKIP Siliwangi, Cimahi \\ *astutisupartinah20@gmail.com
}

\begin{tabular}{|l|l|l|l|}
\hline Received: 25-02-2021 & Revised: 14-05-2021 & Accepted: 24-05-2021 & Published: 06-06-2021 \\
\hline
\end{tabular}

\begin{abstract}
ABSTRAK
Penelitian ini dilatar belakangi adanya siswa yang tidak dapat menyelesaikan soal pada materi Sistem Persamaan Linear Tiga Variabel dan rendahnya kemampuan siswa dalam mengaitkan masalah dengan kehidupan sehari-hari atau yang bersifat kontekstual. Penelitian ini bertujuan untuk mengidentifikasi kesulitan siswa dalam menyelesaikan materi Sistem Persamaan Linear Tiga Variabel. Subjek dari penelitian ini adalah siswa kelas X Madrasah Aliyah di Cianjur yang berjumlah 30 orang. Metode yang digunakan dalam penelitian ini adalah metode kuantitatif. Instrumen untuk mendapatkan data itu sendiri dilakukan dengan tes yang diberikan kepada siswa berupa lembar soal yang berisi 5 butir soal dengan soal yang memiliki tingkat kesulitan yang berbeda-beda. Hasil yang diperoleh dari penelitian ini adalah kesalahan yang paling sering dilakukan siswa yakni: 1) Siswa tidak menjawab soal 5\%,2) Siswa tidak dapat membuat model matematika 5\%,3) Siswa salah membuat model matematika 10\%,4) Siswa salah melakukan eliminasi $10 \%, 5)$ Siswa salah menuliskan tanda operasi pada persamaan untuk dieliminasi 5\%,6) Siswa salah menghitung pada saat mengeliminasi $30 \%$, 7) Siswa salah membuat persamaan baru untuk disubstitusikan 20\%,8) Siswa salah memasukan nilai substitusi 25\%, dan 9) Siswa salah mengitung pada saat mensubstitusi 40\%. dalam menyelesaikan Sistem Persamaan Linear Tiga Variabel.

Kata Kunci : Kesalahan Siswa, SPLTV, Konstektual.
\end{abstract}

\section{ABSTRACT}

This research was motivated by the existence of students who could not solve problems on the material of the Three Variable Linear Equation System and the students' low ability to relate problems with everyday life or contextual ones. This study aims to determine the difficulties of students in completing the material for the Three Variable Linear Equation System. The subjects of this study were 30 students of class X Madrasah Aliyah Cianjur. The method used in this research is quantitative method. The instrument for obtaining the data itself was carried out by a test given to students in the form of a question sheet containing 5 items with questions having different levels of difficulty. The results obtained from this study were the mistakes most often made by students, namely: 1) Students did not answer 5\%, 2) Students could not make 5\% mathematical models, 3) Students made 10\% wrong mathematical models, 4) Students did wrong 10\% elimination, 5) Students incorrectly wrote the operation sign in the equation to be eliminated 5\%, 6) Students miscalculated when eliminating 30\%, 7) Students made new equations to substitute 20\%, 8) Students incorrectly entered the substitution value of 25\%, and 9) Students miscalculated when substituting 40\%. in solving the Three Variable Linear Equation System.

Keywords: Student Error, SPLTV, Contextual. 


\section{PENDAHULUAN}

Matematika merupakan salah satu ilmu yang memiliki peranan penting dalam kehidupan manusia, dan ilmu yang membekali siswa dengan kompetensi berpikir logis, analitis, sistematis, kritis, dan kreatif serta kemampuan bekerjasama (Depdiknas, 2003). Bagian terpenting dalam mempelajari matematika adalah proses dari pembelajaran itu sendiri. Terdapat lima standar isi dalam pembelajaran matematika disekolah, yakni 1) Bilangan dan Operasinya, 2) Aljabar, 3) Geometri, 4) Pengukuran, serta 5) Analisis Data dan Probabilitas (Ulfah et al. 2019). Matematika merupakan salah satu bagian yang penting dalam bidang ilmu pengetahuan (Ari Septian \& Komala, 2019). Apabila dilihat dari sudut pengklasifikasian bidang ilmu pengetahuan, matematika termasuk ke dalam ilmu-ilmu eksakta yang lebih banyak memerlukan berpikir kreatif dari pada hapalan (Andiyana et al. 2018)

Aljabar merupakan salah satu ruang lingkup dalam matematika yang mempelajari penyederhanaan dan pemecahan masalah menggunakan simbol (Widiyawati, Septian, \& Inayah, 2020). Simbol digunakan untuk mempresentasikan bilangan secara umum sebagai sarana penyederhanaan dan alat bantu memecahkan permasalahan (Nugraha \& Santika, 2020). Sebagai salah satu ruang lingkup matematika, aljabar dipelajari diberbagai jenjang pendidikan dan dibagi menjadi beberapa pokok bahasan di setiap jenjang salah satunya adalah Sistem Persamaan Linear Tiga Variabel (SPLTV). Sejalan dengan pendapat (Kuswanti, Sudirman, \& Nusantara, 2018). Kesalahan yang dilakukan, seperti siswa gagal dalam mengumpulkan informasi penting yang ada pada soal, siswa salah dalam membuat model matematika yang sesuai, dan siswa melakukan kesalahan saat melakukan perhitungan (Jusniani, 2018).

Kesalahan Indikator ketercapaian kompetensi meliputi: 1) Menyusun model matematika dari masalah kontekstual kedalam bentuk sistem persamaan linear tiga variabel, 2). Menentukan himpunan penyelesaian sistem persamaan linear tiga variabel dengan metode substitusi, metode eliminasi, metode gabungan (eliminasi substitusi), dan metode determinan, 3) Menyelesaikan masalah kontesktual yang berkaitan dengan sistem persamaan linear tiga variabel. Berdasarkan hasil observasi yang telah dilakukan, banyak siswa yang mengalami kesalahan pada saat menyelesaikan Sistem Persamaan Linear Tiga Variabel. Terlihat dari banyaknya jawaban yang belum tepat yang dilakukan siswa saat mengerjakan soal Sistem Persamaan Linear Tiga Variabel. Kebanyakan siswa sudah mulai membuat kesalahan pada saat memodelkan soal cerita ke dalam model matematika. Siswa juga bingung dalam menentukan metode apa yang harus digunakan saat menyelesaikan 
soal walaupun sudah diberikan kebebasan untuk memilih metode penyelesaiannya. Dilanjutkan dengan kesalahan berikutnya yakni melakukan kesalahan saat melakukan substitusi ataupun eliminasi.

Kesalahan yang dilakukan siswa tidak dapat dibiarkan begitu saja karena hal ini bisa menghambat siswa menyelesaikan soal. Oleh karena itu, dibutuhkan suatu analisis terhadap kesalahan yang dilakukan siswa, agar dapat mengetahui alasan siswa melakukan kesalahan. Analisis kesalahan merupakan studi yang dilakukan terhadap pekerjaan siswa dengan tujuan untuk mencari alasan terjadinya kesalahan yang dilakukan. Analisis kesalahan ini dilakukan bukan hanya untuk menganalisis langkah pekerjaan siswa yang sepenuhnya benar, sebagian benar, atau yang salah dalam mencari solusi. Juga merupakan solusi terbaik yang dapat digunakan untuk memperbaiki pembelajaran.

Berdasarkan uraian diatas, studi ini bertujuan untuk mengidentifikasi kesalahankesalahan siswa di Madrasah Aliyah di Kabupaten Cianjur dalam menyelesaikan materi sistem persamamaan linear tiga variabel.

\section{METODE PENELITIAN}

Metode yang digunakan dalam penelitian ini adalah metode deskriptif kuantitatif. Subjek penelitian adalah siswa Madrasah Aliyah di Cianjur yang terdiri dari 30 siswa, tahun pelajatn 2020 - 2021. Dilakukannya penelitian ini adalah untuk mengidentifikasi kesulitan yang dialami siswa dalam menyelesaikan materi Sistem Persamaan Linear Tiga Variabel. Teknik pengumpulan data menggunakan instrumen soal tes uraian sesuai dengan indikator pembelajaran Sistem Persamaan Linear Tiga Variabel untuk mengidentifikasi kesulitan siswa dalam materi Sistem Persamaan Linear Tiga Variabel. Adapun teknik pengolahan data dalam penelitian ini dilakukan dengan cara menganalisis data pada saat pengumpulan data berlangsung. Aktivitas dalam menganalisis data meliputi, 1) reduksi data, 2) penyajian data, 3) penarikan kesimpulan dan verifikasi, (Aisyah, 2016). Strategi penelitian yang digunakan adalah metode deskriptif kuantitatif, yaitu penelitian yang berusaha untuk mendeskripsikan suatu gejala peristiwa secara sistematis dan akurat mengenai sifat-sifat populasi atau daerah tertentu (Alham Syukman Siasa, 2018). Berikut adalah diagram penelitianya: 


\section{Diagram Penetilian}

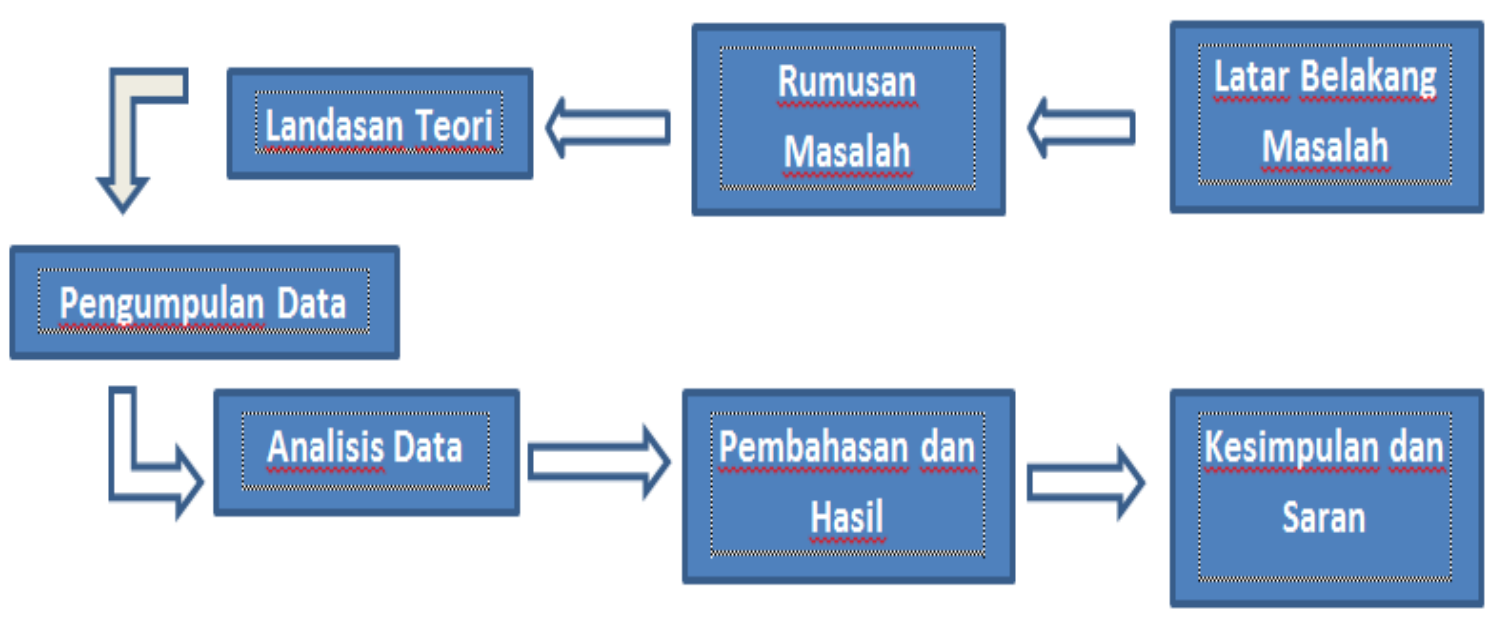

Gambar 1. Diagram Penelitian

\section{HASIL DAN PEMBAHASAN}

Rohimah (2017) berpendapat bahwa hambatan belajar yang ditemukan pada materi Sistem Persamaan Linear Tiga Variabel yang dialami siswa dikategorikan menjadi 3 jenis, yakni: 1) ontogenic obstacle, loncatan berpikir siswa dari pola pikir aritmatika ke pola pikir aljabar. 2) epistemology obstacle, keterbatasan konteks pada siswa yang menyebabkan kesalahan dalam menyelesaikan soal. 3), didactical obstacle kesulitan yang terjadi akibat pembelajaran yang dilakukan guru. Kesalahan diidentifikasi melalui jawaban siswa yang diperoleh dengan melakukan uji coba soal uraian. Berdasarkan hasil uji coba dapat diidentifikasi bahwa kesalahan yang sering dialami siswa yakni, 1) Siswa tidak menjawab soal, 2) Siswa tidak dapat membuat model matematika, 3) Siswa salah membuat model matematika, 4) Siswa salah melakukan eliminasi, 5) Siswa salah menuliskan tanda operasi pada persamaan untuk dieliminasi, 6) Siswa salah menghitung pada saat mengeliminasi, 7) Siswa salah membuat persamaan baru untuk disubstitusi, 8) Siswa salah memasukan nilai substitusi, dan 9) Siswa salah mengitung pada saat mensubstitusi. Hal ini selaras dengan penelitian yang telah dilakukan oleh (Dini et al. 2018) bahwa kesalahan yang sering dilakukan siswa saat menjawab soal Sistem Persamaan Linear Tiga Variabel adalah pada operasi hitung aljabar. Kesalahan siswa dalam menyelesaikan Sistem Persamaan Linear Tiga Variabel dapat di lihat di Gambar.2 


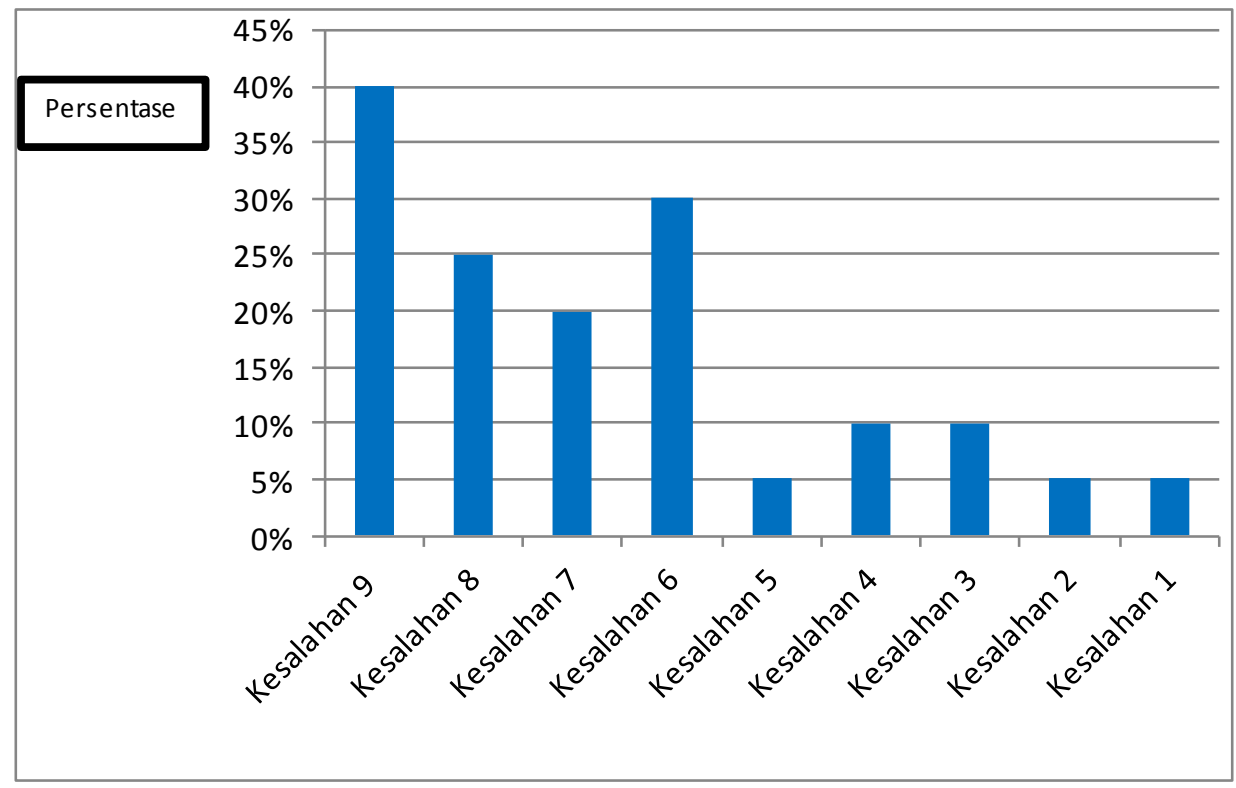

Gambar 2. Kesalahan Siswa

Berdasarkan Gambar 2 kesalahan yang paling sering dilakukan siswa yakni: 1) Siswa tidak menjawab soal 5\%,2) Siswa tidak dapat membuat model matematika 5\%, 3) Siswa salah membuat model matematika 10\%, 4) Siswa salah melakukan eliminasi 10\%, 5) Siswa salah menuliskan tanda operasi pada persamaan untuk dieliminasi 5\%, 6) Siswa salah menghitung pada saat mengeliminasi $30 \%, 7)$ Siswa salah membuat persamaan baru untuk disubstitusikan 20\%, 8) Siswa salah memasukan nilai substitusi 25\%, dan 9) Siswa salah mengitung pada saat mensubstitusikan $40 \%$. Kesalahan - kesalahan siswa dalam penyelesaian soal - soal Sistem Persamaan Linear Tiga Variabel yang paling banyak adalah salah pada saat mensubstitusikan, Berikut diantaranya kesalahan siswa pada Gambar. 3:

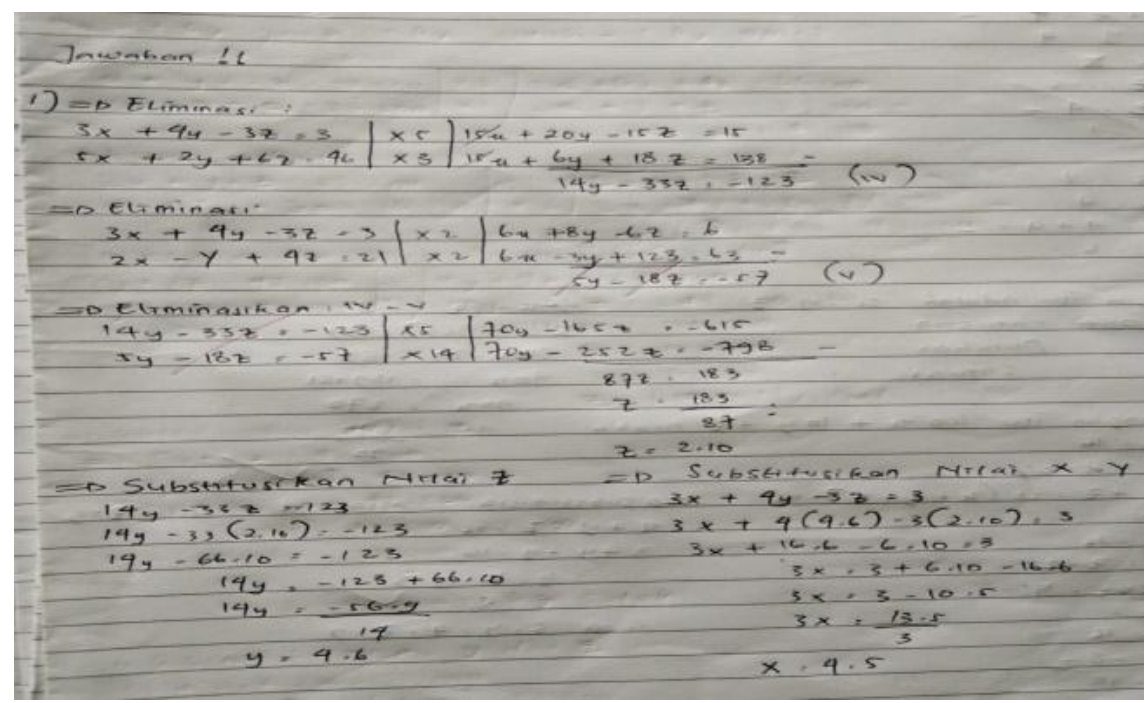

Gambar 3. Contoh Kesalahan dalam SPLTV 
Berdasarkan Gambar 3 masih banyak kesalahan dalam mensubstitusikan, Pada saat membuat persamaan baru untuk disubstitusi dengan persamaan lainnya siswa sudah mengoperasikan persamaannya. Sehingga untuk langkah berikutnya sampai akhir siswa tidak dapat menemukan jawaban yang tepat, jika melihat dari kesalahan-kesalahan yang dilakukan siswa dapat dikategorikan siswa sudah memahami namun terkendala dengan kemampuan konsep operasi aljabar. Menurut (Aida et al. 2017) Kemampuan pemahaman konsep merupakan kemampuan siswa untuk dapat mengerti konsep yang diajarkan guru. Yang menyebabkan kesalahan menurut (Surya, 2012) terdapat tujuh peranan visualisasi yakni : 1) untuk memahami masalah, 2) untuk menyederhanakan masalah, 3) untuk melihat keterkaitan masalah, 4) memahami gaya belajar individual, 5) sebagai alat pengganti komputasi/ perhitungan, 6) sebagai alat untuk memeriksa solusi, dan 7) untuk mengubah masalah ke dalam bentuk matematis.

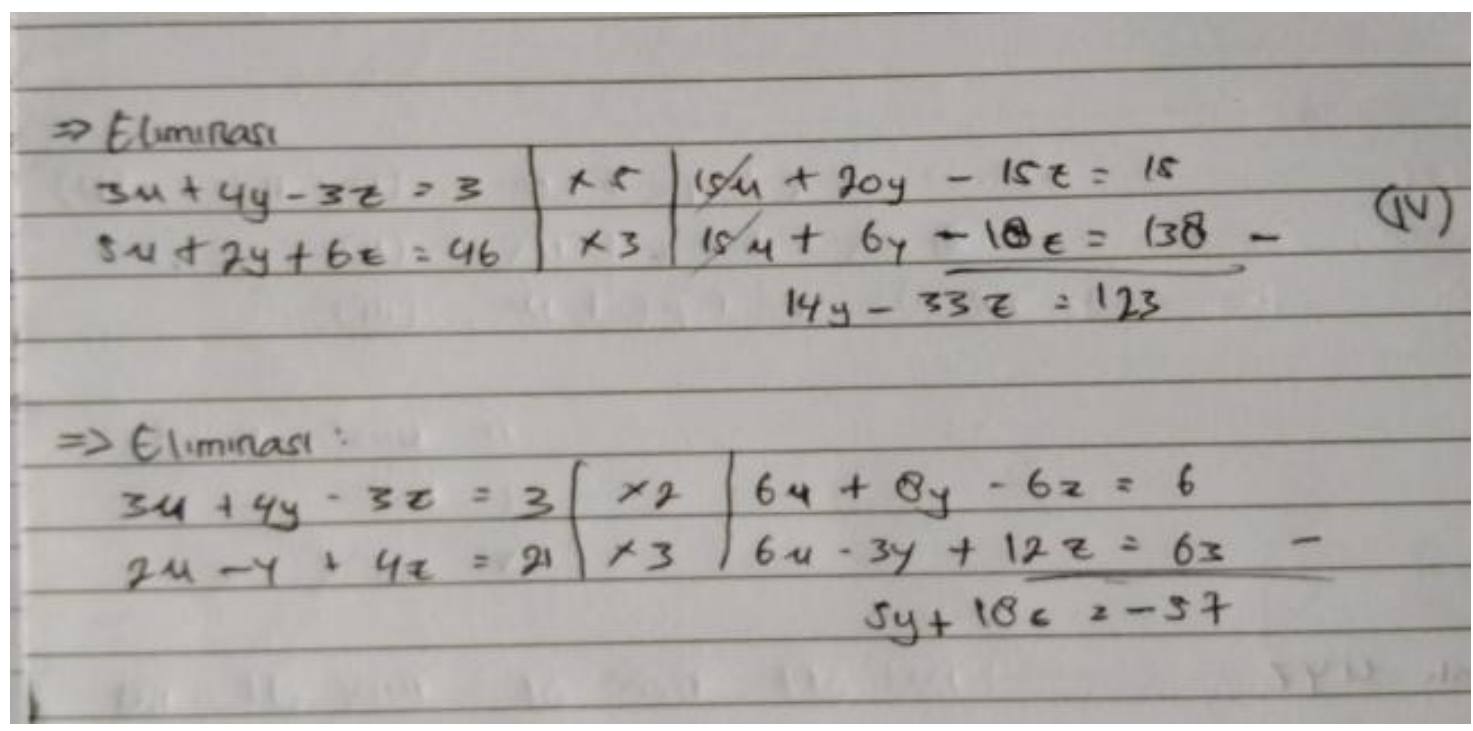

Gambar 4

Berdasarkan Gambar 4 terlihat bahwa siswa masih banyak yang salah menghitung pada saat mengeliminasi. Kesalahan-kesalahan umum yang sering terjadi dalam menyelesaikan soal-soal matematika diantaranya yaitu kesalahan dalam memahami konsep dan rumus matematika, kesalahan hitung, kesalahan dalam memahami simbol dan tanda, kesalahan dalam memilih dan menggunakan prosedur penyelesaian. Oleh karena itu, untuk memahami konsep matematika perlu memperhatikan konsep - konsep yang sebelumnya dipelajari. (Hanipa et al. 2012). Hal ini juga sejalan dengan pendapat (Rofi'ah et al. 2019) yang mengemukan salah satu kesalahan siswa itu adalah tidak menuliskan pemisalan dari variabel yang digunakan, sehingga tidak sedikit siswa yang melakukan kesalahan dalam 
menyelesaikan permasalahan tersebut. Hal ini sejalan dengan penelitian (Azzahra, 2019) bahwa faktor penyebab kesalahan siswa dalam menyelesaikan soal cerita antara lain keinginan siswa untuk menyingkat penulisan jawaban, ketidaksadaran siswa bahwa kalimat/model matematika yang dia tuliskan adalah salah, siswa merasa kebingungan, kekurang telitian siswa dalam melakukan penghitungan, dan kurang terbiasanya siswa dalam menuliskan kesimpulan.

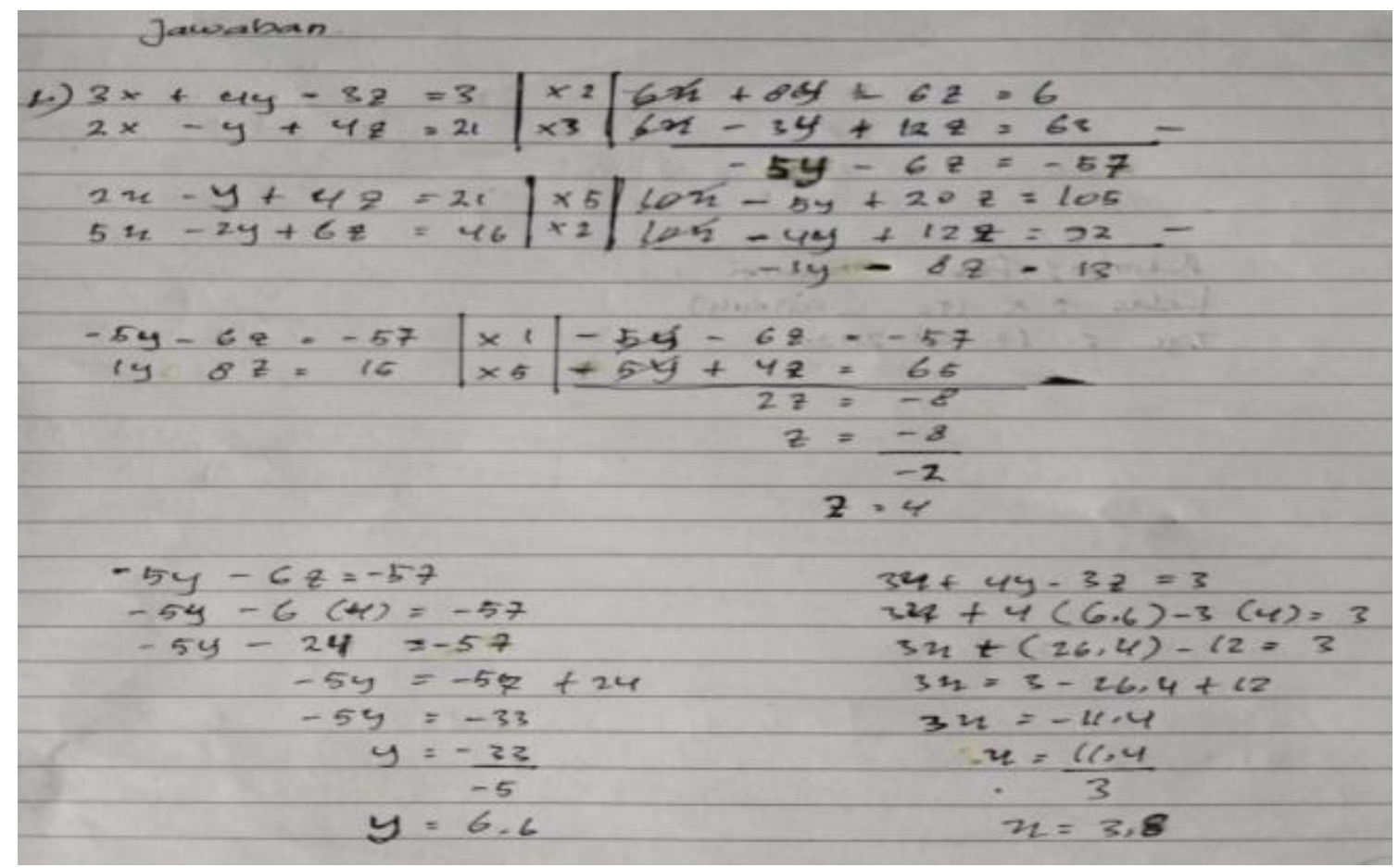

Gambar 5. Contoh Kesulitan dalam Metode Eliminasi

Berdasarkan Gambar 5 terlihat bahwa siswa masih kesulitan dalam menyelesaikan soal tersebut dengan menggunakan metode eliminasi dalam proses pengurangan dan penjumlahannya, sehingga hasilnya belum benar, pada saat mengerjakan siswa kurang teliti dalam perhitungan yang dilakukan. Selain menggunakan metode eliminasi siswa juga menggunakan metode substitusi. Sehingga untuk langkah berikutnya sampai akhir siswa tidak menemukan penyelesaian yang tepat. Penyelesaian adalah keseluruhan proses yang dilakukan siswa dalam menyelesaikan suatu masalah matematika dari awal sampai akhir proses tersebut (Alham, 2018). Selain itu salah satu faktor kesalahan siswa adalah terburuburu dalam membaca dan memahami soal serta lupa akan metode atau prosedur penyelesaian yang tepat (Hidayat, 2018). Menurut Supardi (2013) keberhasilan siswa dalam pembelajaran tergantung pada bagaimana cara siswa mengatasi kesulitan yang ada. Cara mengatasi kesulitan setiap orang berbeda-beda. Demikian pula, tingkat kecerdasan seseorang relative berbeda. 
Kesalahan dalam membaca soal terjadi karena siswa tidak mengerti informasi penting yang ada pada masalah yang diberikan, siswa tidak dapat menentukan informasi dan simbol matematika yang tepat, dan siswa tidak menyelesaikan sama sekali masalah yang diberikan. Keberhasilan siswa pada langkah ini akan memengaruhi langkah yang akan digunakan siswa dalam penyelesaian masalah. Meskipun semua siswa dapat membaca soal dengan lancar dan benar, namun hal tersebut tidak cukup menjamin siswa dapat menyelesaikan masalah dengan benar. Pernyataan tersebut didukung oleh pendapat (Andanik \& Fitrianawati, 2019) yang menyatakan bahwa membaca merupakan proses rumit yang melibatkan melafalkan tulisan, aktivitas visual, dan berpikir. Oleh sebab itu, kelancaran membaca siswa tidak dapat dijadikan acuan untuk menentukan keberhasilan siswa dalam menyelesaikan masalah.

Kesalahan siswa pada memahami masalah terjadi karena siswa tidak dapat menentukan/menuliskan apa yang diketahui dan ditanyakan masalah. (Buchanan, Paul, Buchanan, \& Paul, 2007) berpendapat bahwa reading dan comprehenssion skill dapat meningkatkan pemahaman siswa terhadap masalah yang diberikan. Selain itu, juga dapat memengaruhi kesuksesan siswa dalam memecahkan masalah. Dapat disimpulkan bahwa menuliskan apa yang diketahui dan ditanyakan itu penting karena dapat mempermudah siswa untuk memahami dan membuat gambaran umum penyelesaian dari masalah yang diberikan.

Kesalahan mentransformasi masalah terjadi karena siswa tidak dapat membuat model matematika yang sesuai dengan masalah yang diberikan (A Septian, Darhim, \& Prabawanto, 2020). Senada dengan hal tersebut, (Singh, Rahman, \& Hoon, 2010) menyebutkan bahwa siswa gagal mengubah masalah matematika menjadi model matematika. Kesalahan pada langkah ini termasuk sebagai kesalahan yang sering ditemukan pada penelitian ini.

Kesalahan keterampilan proses terjadi karena siswa tidak berhasil melaksanakan prosedur perhitungan yang telah direncanakan. Selain itu, kesalahan keterampilan proses juga disebabkan oleh ketidaktelitian siswa selama melakukan proses perhitungan. Kesalahan keterampilan proses merupakan kesalahan yang paling sering ditemukan pada penelitian ini, selain kesalahan mentransformasi masalah dan menuliskan jawaban akhir.(Ellerton \& Clements, 1996) mengungkapkan bahwa tujuan dari Newman menggunakan kata "hierarki" pada setiap langkah penyelesaian masalah adalah untuk menunjukkan bahwa setiap langkah penyelesaian masalah saling memengaruhi satu sama lain. Dengan kata lain, apabila siswa melakukan kesalahan pada satu langkah sebelumnya, 
maka siswa tersebut pasti akan melakukan kesalahan pada langkah selanjutnya. Oleh sebab itu, kesalahan pada keterampilan proses dan menuliskan jawaban akhir sering terjadi.

Kesalahan yang dilakukan saat menuliskan jawaban akhir terjadi karena siswa telah melakukan kesalahan pada langkah sebelumnya, siswa tidak memeriksa kecocokan antara hasil pekerjaannya dengan informasi yang diberikan, dan siswa tidak menuliskan jawaban akhir sama sekali. Selain itu, berdasarkan wawancara yang dilakukan pada siswa diketahui juga bahwa kesalahan pada langkah ini terjadi karena siswa terbiasa menuliskan jawaban akhir secara singkat tanpa perlu mencocokkan dengan apa yang ditanyakan masalah. (Praktitipong \& Nakamura, 2006) menyatakan bahwa siswa dikatakan berhasil pada langkah menuliskan jawaban akhir, jika siswa dapat menuliskan jawaban dengan tepat dan lengkap. Oleh karena itu, jika siswa tidak dapat menuliskan jawaban akhir secara tepat dan lengkap. Maka siswa tersebut dikatakan melakukan kesalahan dalam menuliskan jawaban akhir.

Kesalahan karena kecerobohan terjadi karena siswa tidak teliti saat menyelesaikan masalah yang diberikan. Ketidak telitian tersebut ditunjukkan saat siswa menginterpretasikan istilah pada masalah yang diberikan. Selain kesalahan tersebut, siswa juga melakukan kesalahan dengan saat membuat persamaan dan melakukan operasi. Menurut (Dwi \& Hendikawati, 2018) menyebutkan bahwa siswa yang memiliki kemampuan pemahaman konsep yang tinggi pun berpeluang melakukan kesalahan. Siswa yang dapat memahami konsep sekalipun akan gagal menyelesaikan suatu masalah jika tidak teliti. (Hidayat \& Sumarmo, 2013) mengemukakan bahwa dalam pembelajaran matematika tugas guru adalah membantu siswa untuk membangun konsep-konsep matematika dengan kemampuannya sendiri melalui proses internalisasi sehingga membentuk suatu konsep baru yang bermakna. Agar kesalahan - kesalahan dalam penyelesaian masalah dapat dikurangi ada tiga tahap berikutnya adalah membuat rencana, melaksanakan rencana, dan memeriksa kembali (Pasini, 2012).

\section{KESIMPULAN}

Berdasarkan hasil identifikasi terdapat sembilan kesalahan yang dialami siswa saat menyelesaikan soal Sistem Persamaan Linear Tiga Variabel, yakni kesalahan yang paling sering dilakukan siswa yakni: 1) Siswa tidak menjawab soal lima persen, 2) Siswa tidak dapat membuat model matematika lima persen, 3) Siswa salah membuat model matematika sepuluh persen, 4) Siswa salah melakukan eliminasi sepuluh persen, 5) Siswa salah menuliskan tanda operasi pada persamaan untuk dieliminasi lima persen, 6) Siswa salah 
menghitung pada saat mengeliminasi tiga puluh persen, 7) Siswa salah membuat persamaan baru untuk disubstitusi dua puluh persen, 8) Siswa salah memasukan nilai substitusi dua puluh lima persen, dan 9) Siswa salah mengitung pada saat mensubstitusi empat puluh persen. Sehingga ada beberapa siswa yang belum dapat menyelesaikan masalah kontekstual yang berkaitan dengan sistem persamaan linear tiga variabel. Dengan melihat indikator pembelajaran dari SPLTV yang meliputi: 1) Siswa dapat menyusun model matematika dari masalah kontekstual ke dalam bentuk sistem persamaan linear tiga variabel, 2) Siswa dapat menentukan himpunan penyelesaian sistem persamaan linear tiga variabel dengan metode substitusi, metode eliminasi, metode gabungan (eliminasisubstitusi), dan metode determinan, dan 3) siswa dapat menyelesaikan masalah kontesktual yang berkaitan dengan sistem persamaan linear tiga variable dan melihat kesalahankesalahan yang dialami atau dilakukan siswa selama menyelesaikan soal tes uraian terlihat bahwa indikator pembelajaran belum tercapai. Karena kesalahan yang paling tinggi dari tiga puluh orang siswa yaitu ada empat puluh persen yang belum benar mensubstitisikan, tiga puluh persen salah menghitung pada saat eliminasi. Masalah matematika juga membantu siswa mengaitkan pengetahuan yang dipelajari dalam kelas dengan kehidupan sehari-hari, dan dengan pengetahuan lainnya.

\section{REFERENSI}

Aida, N., Kusaeri, K., \& Hamdani, S. (2017). Karakteristik Instrumen Penilaian Hasil Belajar Matematika Ranah Kognitif yang Dikembangkan Mengacu pada Model PISA. $\begin{array}{lllll}\text { Suska Journal of Mathematics } & 130 .\end{array}$ https://doi.org/10.24014/sjme.v3i2.3897

Aisyah, A. (2016). Analisis Kemampuan Penalaran Logis Mahasiswa Program Studi Pendidikan Matematika Pada Mata Kuliah Pengantar Dasar Matematika. Jurnal Ilmiah Dikdaya, 6(2), 1-11.

Andanik, R. T., \& Fitrianawati, M. (2019). Pengaruh Keterampilan Membaca Pemahaman Terhadap Kemampuan Pemecahan Soal Cerita Matematika Siswa Kelas V Sekolah Dasar. Jurnal Fundadikdas (Fundamental Pendidikan Dasar), 2(2), 40. https://doi.org/10.12928/fundadikdas.v2i2.836

Andiyana, M. A., Maya, R., \& Hidayat, W. (2018). Analisis Kemampuan Berpikir Kreatif Matematis Siswa Smp Pada Materi Bangun Ruang. JPMI (Jurnal Pembelajaran Matematika Inovatif), 1(3), 239. https://doi.org/10.22460/jpmi.v1i3.p239-248

Azzahra, S. J. (2019). Analisis Kesalahan Siswa dalam Pemahaman Konsep Menyelesaikan Soal Cerita SPLDV dengan Tahapan Newman. Jurnal Pembelajaran Matematika Inovatif, 2(2), 87-94.

Buchanan, T., Paul, S., Buchanan, T., \& Paul, S. (2007).DigitalCommons @ University of Nebraska - Lincoln The Importance of Teaching Students How to Read to Comprehend Mathematical Language The Importance of Teaching Students How to Read to Comprehend Mathematical Language Math in the Middle Institute Partners. Depdiknas. (2003). Kurikulum Berbasis Kompetensi Mata Pelajaran Matematika. 6. 
Di Perri, G., Cazzadori, A., Vento, S., Bonora, S., Malena, M., Bontempini, L., ... Concia, E. (1996). Comparative histopathological study of pulmonary tuberculosis in human immunodeficiency virus-infected and non-infected patients. Tubercle and Lung Disease, 77(3), 244-249. https://doi.org/10.1016/S0962-8479(96)90008-8

Dini, M., Nuraeni, N., \& Anita, I. W. (2018). Meningkatkan Kemampuan Pemahaman Matematis Siswa SMK Menggunakan Pendekatan Kontekstual Pada Materi SPLTV. IndoMath: Indonesia Mathematics $\quad$ Education, $\quad$ l(1), 49. https://doi.org/10.30738/indomath.v1i1.2218

Dwi, N., \& Hendikawati, P. (2018). The mathematical problem solving ability of student on learning with Thinking Aloud Pair Problem Solving (TAPPS) model in term of student learning style. Unnes Journal of Mathematics Education, 7(1), 1-7. https://doi.org/10.15294/ujme.v7i1.18870

Ellerton, N. F., \& Clements, M. A. (1996). Newman Error Analysis: A Comparative Study Involving Year 7 Students in Malaysia and Australia Nerida F. Technology in Mathematics Education, 186-193.

Hanipa, A., \& Sari, V. T. A. (2019). Sistem Persamaan Linear Dua Variabel Pada Siswa. Journal On Education, 01(02), 15-22.

Hidayat, W., \& Sumarmo, U. (2013). Kemampuan Komunikasi dan Berpikir Logis Matematik serta Kemandirian Belajar. Delta-Pi: Jurnal Matematika Dan Pendidikan Matematika, 2(1), 1-14.

Jusniani, N. (2018). Analisis Kesalahan Jawababn Siswa Pada Kemampuan Pemahaman Matematis Melalui Pembelajaran Kontekstual. Prisma, VII(1), 82-90.

Kuswanti, Y., Sudirman, \& Nusantara, T. (2018). Deskripsi Kesalahan Siswa pada Penyelesaian Masalah Sistem Persamaan Linear Tiga Variabel ( SPLTV ). Jurnal Pendidikan: Teori, Penelitian, Dan Pengembangan, 3(7), 865-872.

Nugraha, D. A., \& Santika, S. (2020). Distribusi Kemampuan Berpikir Matematik Tingkat Tinggi pada Siswa Sekolah Menengah Atas Kota Tasikmalaya Tahun Pelajaran 2018/2019. Prisma, 9(1), 20. https://doi.org/10.35194/jp.v9i1.787

Pasini. (2012). Kemampuan Siswa SMA Dalam Menyelesaiakn Masalah Sistem Persamaan Linear Tiga Variabel. Juurnal Edukasi, 2.

Praktitipong, N., \& Nakamura, S. (2006). Analysis of Mathematics Performance of Grade Five Students in Thailand Using Newman Procedure. Journal of International Cooperation in Education, 9(1), 111-112.

Rofi'ah, N., Ansori, H., \& Mawaddah, S. (2019). Analisis Kesalahan Siswa Dalam Menyelesaikan Soal Cerita Matematika Berdasarkan Langkah Penyelesaian Polya. $\begin{array}{llll}\text { EDU-MAT: } \quad J u r n a l & \text { Pendidikan }\end{array}$ https://doi.org/10.20527/edumat.v7i2.7379

Rohimah, S. M. (2017). Analisis Learning Obstacles Pada Materi Persamaan Dan Pertidaksamaan Linear Satu Variabel. Jurnal Penelitian Dan Pembelajaran Matematika, 10(1). https://doi.org/10.30870/jppm.v10i1.1293

Septian, A, Darhim, \& Prabawanto, S. (2020). Geogebra in integral areas to improve mathematical representation ability. Journal of Physics: Conference Series, 1613, 012035. https://doi.org/10.1088/1742-6596/1613/1/012035

Septian, Ari, \& Komala, E. (2019). Kemampuan Koneksi Matematik dan Motivasi Belajar Siswa dengan Menggunakan Model Problem-Based Learning (PBL) Berbantuan Geogebra di SMP. PRISMA, 8(1), 1-13. https://doi.org/10.35194/jp.v8i1.438

Siasa, A. S., Salam, M., \& Suhar, S. (2019). Analisis Kesulitan Belajar Matematika Pada Materi Sistem Persamaan Linear Tiga Variabel Kelas X 1 Sma Negeri 10 Kendari. Jurnal Penelitian Pendidikan Matematika, 6(1), 1. https://doi.org/10.36709/jppm.v6i1.7333 
Singh, P., Rahman, A. A., \& Hoon, T. S. (2010). The Newman procedure for analyzing Primary Four pupils errors on written mathematical tasks: A Malaysian perspective. Procedia - Social and Behavioral Sciences, 8(5), 264-271. https://doi.org/10.1016/j.sbspro.2010.12.036

Surya, E. (2012). Visual Thinking Dalam Memaksimalkan Pembelajaran Matematika Siswa Dapat Membangun Karakter Bangsa. Jurnal Penelitian Dan Pembelajaran Matematika, 5(1), 41-50.

Ulfah, M., Felicia, L., \& Pendahuluan, A. (2019). Pengembangan Pembelajaran Matematika Dalam National Council of Teachers of Mathematics ( Nctm ) Pada Anak. 1(2).

Widiyawati, W., Septian, A., \& Inayah, S. (2020). Analisis Kemampuan Koneksi Matematis Siswa SMK pada Materi Trigonometri. Jurnal Analisa, 6(1), 28-39. https://doi.org/10.15575/ja.v6i1.8566 